ZOOLOGIA 32 (1): 41-46, February 2015

http://dx.doi.org/10.1590/S1984-46702015000100006

\title{
A new species of Kingsleya (Crustacea: Decapoda: Pseudothelphusidae) from the Xingu River and range extension for Kingsleya junki, freshwater crabs from the southern Amazon basin
}

\author{
Manuel Pedraza1, José Eduardo Martinelli-Filho² \& Célio Magalhães ${ }^{3,4}$
}

\author{
'Programa de Pós-Graduação, Museu de Zoologia, Universidade de São Paulo. Avenida. Nazaré 481, Ipiranga, \\ 04263-000 São Paulo, SP, Brazil. E-mail: manupedrazam@gmail.com \\ ${ }^{2}$ Faculdade de Oceanografia, Instituto de Geociências da Universidade Federal do Pará. Campus Universitário do Guamá, \\ 66075-110 Belém, PA. Brazil. \\ 3Instituto Nacional de Pesquisas da Amazônia. Caixa Postal 2223, 69080-971 Manaus, AM, Brazil. \\ ${ }^{4}$ Corresponding author. E-mail: celiomag@inpa.gov.br
}

\begin{abstract}
Kingsleya castrensis sp. nov., a pseudothelphusid crab is described and illustrated from the Xingu River, state of Pará, southern Amazon region, Brazil. The new species is characterized by the male first gonopod bearing a large, well-developed apical plate, with a broadly rounded, thick distal lobe. New records of Kingsleya junki Magalhães, 2003 extend the distribution of this species eastward to the Tocantins River basin, in the state of Pará, Brazil.
\end{abstract}

KEY WORDS. Amazon; Brachyura; Kingsleyini; Neotropical region; taxonomy.

Kingsleya Ortmann, 1897 currently comprises seven species that are all distributed in the highlands of the Guyanan and Central Brazilian Shields. This area encompasses a large portion of northern South America from southern Venezuela, Guyana, Suriname, and French Guiana to the northern Brazilian states of Amazonas, Pará and Roraima (MagalHães 2003a, MagalHães \& TÜrRAY 2008). In Brazil, species of this genus occurs in tributaries of the Amazon River draining the Guyana Shield where it is represented by K. latifrons (Randall, 1840) (in Rio Branco, Rio Negro, and Rio Trombetas), and by K. siolii Bott, 1967 (in Rio Trombetas and Rio Paru do Oeste); and the Central Brazilian Shield: Kingsleya gustavoi Magalhães, 2005 (Rio Tocantins), and K. junki Magalhães, 2003 (Xingu River). Kingsleya ytupora Magalhães, 1986 (found in the Rio Uatumã, Rio Trombetas, Rio Curuá-Una, Rio Xingu) is the only species known to occur on both sides of the Amazon valley (MAGALHÃES 1986, 2003a, b, MagalHães \& TÜrKaY 2008).

Although pseudothelphusids living in high altitude localities typically have restricted distributions, this may not be the case for species living in the Amazon basin which have wide distributions (although much of the southern Amazon River tributaries are still poorly surveyed for decapods). Crab samples sporadically collected during ichthyological and entomological expeditions to the middle and lower course of the Xingu River were studied by MagalHãES (2003b) and indicated that five species occur in this stretch of the river basin: two pseudothelphusids (K. junki and K. ytupora) and three trichodactylids - Sylviocarcinus devillei H. Milne Edwards, 1853,
S. pictus (H. Milne-Edwards, 1953), and Trichodactylus ehrhardti Bott, 1969. Recent collections from southern tributaries of the Amazon river revealed the presence of Kingsleya, including an undescribed species of this genus from the surroundings of the city of Altamira, on the left bank of the middle course of the Xingu River. The new species is herein described and illustrated, and a range extension for $K$. junki is reported.

\section{MATERIAL AND METHODS}

Specimens are deposited at the Instituto Nacional de Pesquisas da Amazônia, Manaus, Brazil (INPA), Museu Nacional, Universidade Federal do Rio de Janeiro, Rio de Janeiro (MNRJ), Museu Paraense Emilio Goeldi, Belém, Brazil (MPEG), Museu de Zoologia, Universidade de São Paulo, São Paulo, Brazil (MZUSP), and Senckenberg Research Institute and Natural History Museum (SMF). The following abbreviations are used: carapace width $(\mathrm{cw})$, measured across the carapace at its widest point; carapace length (cl), measured along the midline, from the frontal to the posterior margin; carapace height (ch), the maximum height of the cephalothorax, measured as the distance between the dorsal and ventral edges of the shell; frontal width (fw), the width of the front measured along its upper border; male first (G1) and second (G2) gonopods; third maxilliped (Mxp3); cheliped (P1); pereiopods 2 to 5 (P2-P5); and sternal sulcus (s). Geographic coordinates inserted between brackets were taken from Google Earth. Illustrations were made using a Leica M8 stereomicroscope with a camera lucida; the

2015 | Sociedade Brasileira de Zoologia | www.sbzoologia.org.br | www.scielo.br/zool All content of the journal, except where identified, is licensed under a Creative Commons attribution-type BY-NC. 
computerized photographs were taken using a stereomicroscope Zeiss Discovery V12 (Automontage ${ }^{\circledR}$ system). Measurements of carapace width and carapace length, in millimeters, were made with a calipers and are given in parentheses after the number of specimens examined. Terminology for describing the morphology of the G1 was adapted from Smalley (1964) and MAgalhães \& TÜrkay (2008).

\section{TAXONOMY}

\section{Kingsleya castrensis sp. nov.}

Figs. 1-4, 7-14

Diagnosis. G1 with large, roughly rounded, thick apical plate, widest medially; proximal lobe of apical plate subtriangular, well developed, situated on mesio-caudal side; distal margin straight, stretching diagonally over the distal lobe, fusing to mesiodistal portion of apical plate; distal lobe of apical plate broad, with lateral margin angulate in mesial view, caudal margin straight, distal margin slightly concave, mesial margin rounded, thick.

Description. Carapace outline ellipsoid, widest medially (cb/cl 1.68); dorsal surface smooth, slightly convex, regions partially defined (Fig. 7). Two distinct gastric pits, close to each other, on metagastric region. Cervical grooves deep, narrow, nearly straight, faint proximally, distal end failing to reach anterolateral margin. Postfrontal lobules small, quite distinct; median groove indistinct. Surface of carapace between front and postfrontal lobules smooth and slightly inclined anteriorly and medially. Upper border of front smooth, angulate, slightly convex in dorsal view, median notch absent; lower border carinate, slightly sinuous in both frontal and dorsal view, more projected anteriorly than upper one, except medially. Upper orbital margin smooth, lower orbital margin slightly crenualte; exorbital angle low, obtuse (Fig. 13). Anterolateral margin of carapace nearly smooth, with very shallow depression just behind exorbital angle, followed by a set of faint, minute teeth increasing in size from the anterior to posterior portion; posterolateral margin smooth, barely defined. Epistome narrow; epistomial tooth triangular, deflexed, with carinate, smooth borders. Suborbital and subhepatic regions of carapace sidewall smooth; pterygostomial regions with narrow pilose patches along outer borders of bucal cavity (Figs. 8 and 13).

Endopod of Mxp3 with outer margin of ischium slightly convex, inner margin straight; outer margin of merus rounded, inner surface of palp covered with large setae; exopod of Mxp3 short, narrow, 0.18 times length of outer margin of ischium (Fig. 14). Aperture of efferent branchial channel wide, upper margin subquadrate, lacking setae (Fig. 13).

First pereiopods heterochelous in both males and females, similarly armed, right P1 usually largest (holotype left P1 major). Major cheliped merus subtriangular in cross section; superior margin rounded with irregular row of tubercles, fainter distally; medial margin lined by longitudinal row of rounded, low teeth, slightly increasing in size distally; inferior lateral margin marked by row of faint tubercles, smooth distally; distal margin arched, smooth laterally, with straight row of faint tubercles mesially. Carpus with inner margin granular proximally, with prominent median spine, smooth distally; outer margin rounded, smooth. Palm narrow (length/breadth 1.61 in holotype), smooth on both sides. Fingers moderately gaping, tips not crossing; both fingers with large triangular teeth sometimes interspaced with small ones, smaller distally. Dactylus distinctly arched, longer then palm (dactylus/palm 1.36 in holotype, measured dorsally), upper, outer surface of dactylus smooth, distomedian portion darker than proximal. Propodal finger with smooth surfaces. P2-5 slender, ratios dactylus/propodus, dactylus/merus (left side measurements in holotype), respectively, as follows: $\mathrm{P} 2=1.80$ and $0.90, \mathrm{P} 3=$ 1.73 and $0.88, \mathrm{P} 4=1.66$ and $0.88, \mathrm{P} 5=1.64$ and 0.92 . P2-5 with dactyli shorter than propodi, bearing five longitudinal rows of sharp, corneous spines, increasing in size distally, 2 faint grooves on the proximal external surface.

Thoracic sternum slightly longer than broad. Thoracic sternites of Mxp3 and P1 completely fused, except for small notches at lateral edges of sternum; s4/s5, s5/s6, s6/s7 distinct, interrupted medially, just failing to reach midline of thoracic sternum; s7/s8 complete, reaching midline. Midline of thoracic sternum marked by deep groove between sternites VII, VIII, deeper at interception with sternal suture $7 / 8$. Episternites 4-6 triangular posteriorly, episternite 7 posteriorly truncate. Sterno-abdominal cavity strongly concave, with few, scattered pubescence. Penis noticeably long, emerging from nearby coxosternal condyle articulation, located in shallow depression on sternite 8 , proximally thick, abruptly tapering distally.

All abdominal segments free. Lateral margins of male telson slightly concave, slightly cranulate, tip rounded (Fig. 8).

G1 (Figs. 1-4 and 9-12) sinuous, broadened distally, with strong median curvature on caudal surface in mesial view, bearing well-developed mesial process. Marginal suture sinuous, displaced to mesial side in distally, bearing several setae proximally. Lateral suture deep, extending $2 / 3$ of gonopod length from proximal portion. Marginal process short, broad, subrectangular in mesial view, not projecting distally beyond field of apical spines area, distal notch in latero-caudal surface. Mesial process well developed, roughly subretangular, approximately 1.8 times longer than apical plate in mesial view, proximal portion rounded, distal portion produced into sharp conical spine pointing in mesial direction; mesial process juxtaposed to the apical plate, both structures clearly separated by a deep incision. Apical plate well developed, large, thick, expanded along caudo-cephalic axis, with 2 juxtaposed lobes; proximal lobe subtriangular, well developed, situated subdistally on mesio-caudal side, narrower than distal lobe, distal margin straight, stretching diagonally over the distal lobe, gradually merging to mesiodistal portion of the apical plate; distal lobe enlarged, caudal margin rather angulate in mesial 

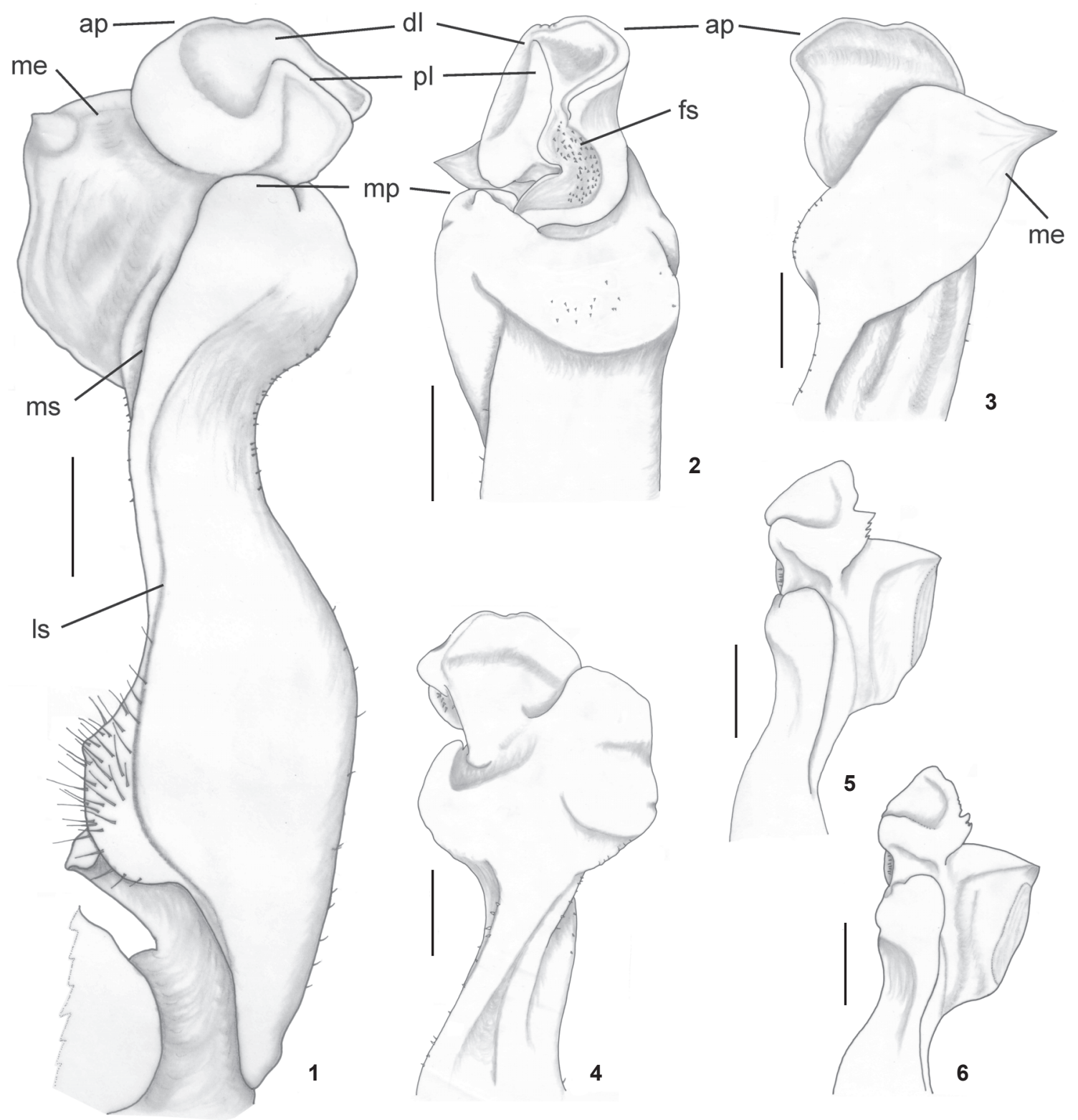

2

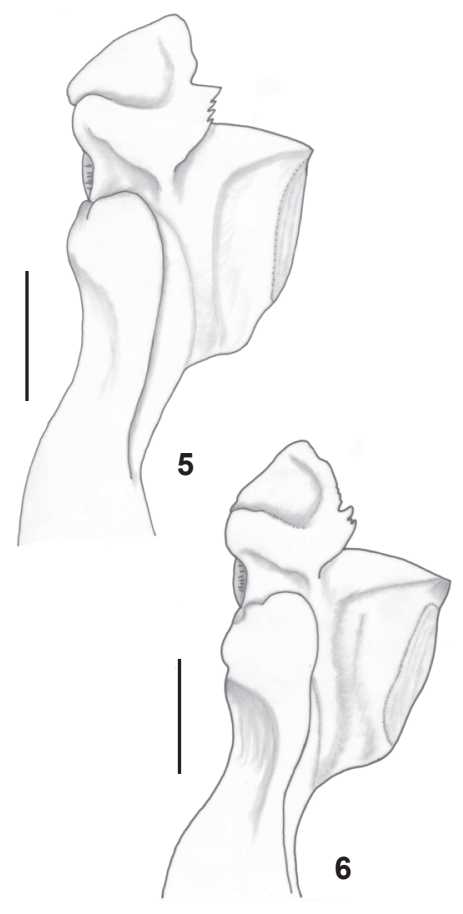

Figures 1-6. (1-4) Kingsleya castrensis sp. nov., male, holotype (cw 46.4mm, cl 27.7mm), left first gonopod, INPA 2010: (1) whole limb, mesial view; (2) distal part, caudal view; (3) distal part, cephalic view; (4) distal part, lateral view. (5-6) Kingsleya junki, male, right first gonopod: (5), distal part, caudal-mesial view, INPA 1708; (6) distal part, caudal-mesial view, INPA 2012. (ap) Apical plate, (dl) distal lobe of apical plate, (fs) field of apical spines, (ls) lateral suture, (me) mesial process, (mp) marginal process, (ms) marginal suture. Scale bars: $1 \mathrm{~mm}$.

view, distal margin slightly concave, mesial margin rounded. Apical spine field well developed, curved, narrow patch of minute spines, longitudinally directed along caudal side of apical plate, delimited by mesial, lateral borders of apical plate, distally opened by distinct notch at apex of apical plates proximal lobe. Sperm channel opening proximally at base of apical spine field.
G2 straight, almost as long as G1 (ca. 0.8 times length of G1), flagellum slender, strongly tapering after distal quarter, tip flattened, with short spinules on sternal surface.

Type material. Brazil, Pará: Altamira (51 ${ }^{\circ}$ B.I.S. - Batalhão de Infantaria de Selva camp area, $\left.3^{\circ} 1147^{\prime \prime S}, 52^{\circ} 0958^{\prime \prime} \mathrm{W}\right)$, male (cw 46.4, cl 27.7, ch 18.3, fw 13.7), holotype, 16.VIII.2011, José E. Martinelli Filho and Cléber S. de Sousa leg., INPA 2010; same 


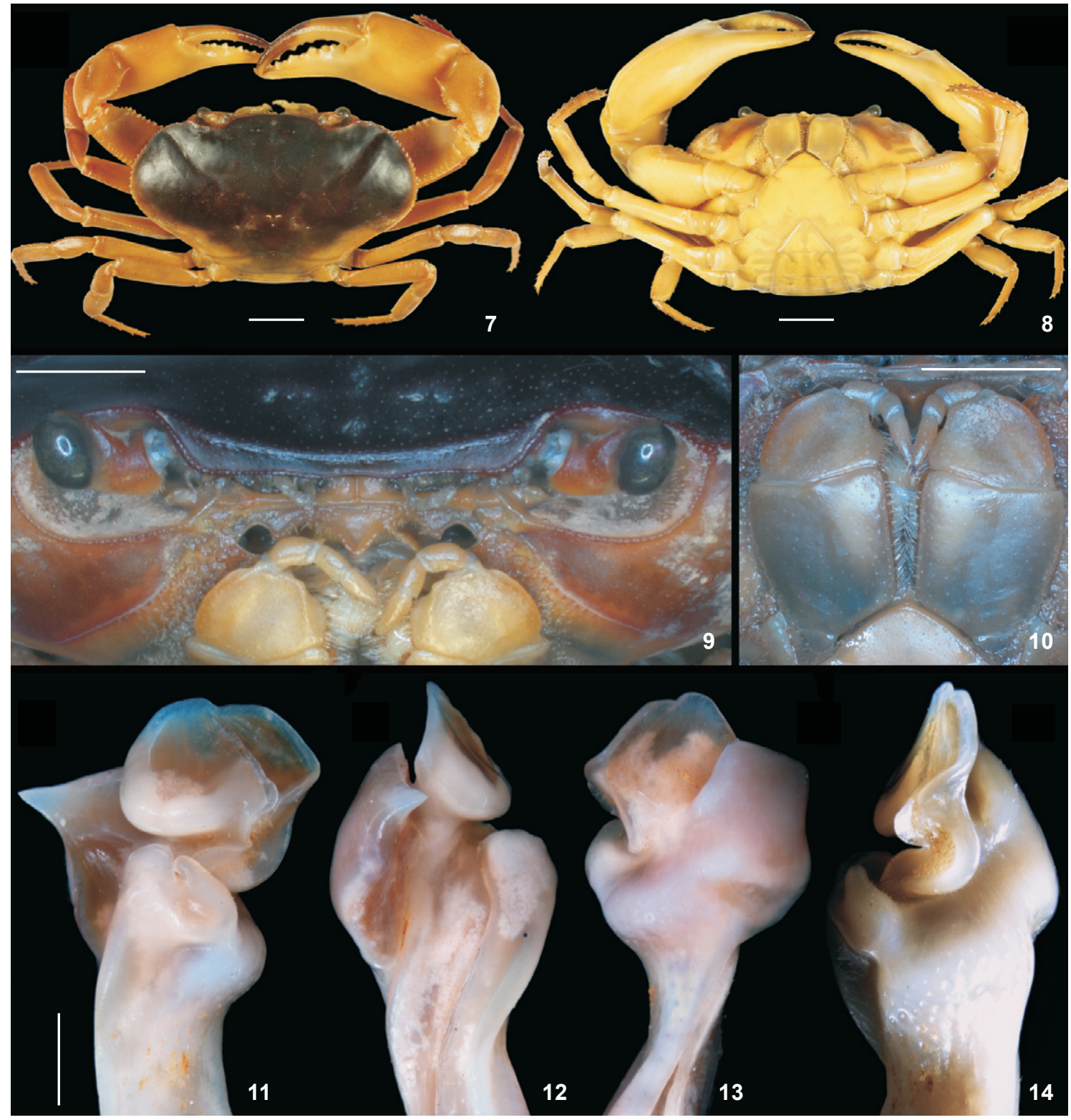

Figures 7-14. Kingsleya castrensis sp. nov., male, paratype, MZUSP 26394: (7) habitus, dorsal view; (8) habitus, ventral view; (9) frontal view; (10) pair of third maxillipeds, frontal view. Male, paratype, left first gonopod, MZUSP 23393: (11) caudal-mesial view; (12) mesial-cephalic view; (13) lateral view; (14) idem, caudal view. Scale bars: 7, $8=10 \mathrm{~mm}, 9,10=5 \mathrm{~mm} ; 11-14=1 \mathrm{~mm}$.

data as holotype, 1 male (cw 40.8, cl 25.1), 3 females (cw 24.7, cl 16.6; cw 46.3, cl 28.4; cw 21.5, cl 14.5), paratypes, 16.VIII.2011, José E. Martinelli Filho and Cléber S. de Sousa leg., INPA 2011; same data as holotype, 4 males (cw 37.2, cl 22.7; cw 37.2, cl 23.3; cw 41.9, cl 25.2; cw 44.1, cl 26.5), paratypes, 26.VIII.2011, Cléber S. de Sousa leg., MPEG 1013; same data as holotype, 2 males (cw 39.7, cl 24.8; cw 42.1, cl 25.7), 1 female (cw 39.0, cl 25.0), paratypes, 26.VIII.2011, Cléber
S. de Sousa leg., SMF 47661; same data as holotype, 1 male (cw 32.2, 20.4), paratype, 28.VIII.2011, José E. Martinelli Filho and Cléber S. de Sousa leg., MNRJ 25117; Altamira (Recanto Cardoso, $3^{\circ} 0920 " \mathrm{~S}, 52^{\circ} 1533 " \mathrm{~W}$ ), 1 male (cw 42.9, cl 27.1), paratype, 9.IV.2012, Ronan Santos leg., INPA 2058; Altamira (Princesa do Xingu road, $\left.3^{\circ} 0935 " \mathrm{~S} 52^{\circ} 1439 " \mathrm{~W}\right), 1$ male, (cw 32.9, cl 21.2), paratype, 6.I.2012, Cléber S. de Sousa leg., INPA 2056; Altamira (Princesa do Xingu road, $\left.3^{\circ} 0942 " \mathrm{~S}, 52^{\circ} 1433^{\prime \prime} \mathrm{W}\right), 1$ male (cw 
34.3, 22.2), paratype, 06.I.2012, Cléber S. de Sousa leg., INPA 2057; Altamira (Abrigo Pedra do Navio, $3^{\circ} 1706.4 " S, 52^{\circ} 13$ 42.2"W), 1 male (cw 32.57, cl 21.08), 11.IV.2012, R. Pinto-daRocha leg., MZUSP 26943; Brasil Novo (Travessão 16, $3^{\circ} 1820 " S$, $52^{\circ} 3540 " \mathrm{~W}$ ), 1 male (cw 31.2, cl 19.8), 1 female $(40.2,25.2)$, paratypes, 13.I.2012, Cléber S. de Sousa leg., MZUSP 32737; Altamira (Pedra da Cachoeira cave, $\left.3^{\circ} 1914.8^{\prime \prime S}, 52^{\circ} 1953.1 " \mathrm{~W}\right)$, 1 male (cw: 49.8, cl: 29.7), paratypes, 20.VI.2012, R. Pinto-daRocha leg., MZUSP 26394.

Additional material examined: Brazil, Pará: Altamira (Princesa do Xingu road, $3^{\circ} 0935^{\prime \prime} \mathrm{S}, 52^{\circ} 1439 " \mathrm{~W}$ ), 1 female (cw 39.8, cl 25.6), 20.I.2012, Cléber S. de Sousa leg., INPA 2061; Altamira (Princesa do Xingu road, $\left.3^{\circ} 0935 " S, 52^{\circ} 1439 " W\right), 1$ male (cw 28.8, cl 18.4), 21.VIII.2011, Cléber S. de Sousa leg., MPEG 1014; Altamira (Princesa do Xingu road, $3^{\circ} 1004$ "S, $52^{\circ} 2156 " W$ ), 1 male (cw 38.7, cl 24.2), 19.VI.2011, Cléber S. de Sousa leg., MZUSP 32738; Altamira (51 B.I.S. - Batalhão de Infantaria de Selva camp area, $\left.3^{\circ} 11478^{\prime \prime S}, 52^{\circ} 0956 " \mathrm{~W}\right), 1$ male (cw 41.5, cl 24.7), 10.XII.2010, José E. Martinelli Filho and Cléber S. de Sousa leg., INPA 2060; Altamira (Arapujá island, $3^{\circ} 1330 " \mathrm{~S}, 52^{\circ} 1213 " \mathrm{~W}$ ), 1 female (cw 37.0, cl 24.0), 10.V.2010, Anderson Prates leg., INPA 2059; Brasil Novo (Travessão 8, $3^{\circ} 2157 " \mathrm{~S}, 52^{\circ} 3218 \mathrm{"W}$ ), 1 male (cw 38.1, cl 24.2), 2 females (cw 28.7, cl 18.9; cw 35.8, cl 28.2), 15.VIII.2012, Cléber S. de Sousa leg., INPA 2062; Altamira (Planaltina cave, $3^{\circ} 2239 " S$, $52^{\circ} 3431 " W$ ), 1 female (cw 27.1, cl 17.4), 17.VIII.2011, Cléber S. de Sousa leg., MPEG 1141.

Type locality and distribution. Brazil, state of Pará, city of Altamira. Most specimens were collected within the camp area of the " $51^{\circ}$ Batalhão de Infantaria de Selva" (B.I.S.), a unit of the Brazilian Armys Battalion of Jungle Infantry, headquartered in the city of Altamira. Additional specimens were also collected in in Altamira and Brasil Novo cities.

Ecological notes. Most of the crabs were collected on the margins of a $1-3 \mathrm{~m}$ wide, third order tributary stream of the Xingu river. The stream is located inside a secondary forest fragment dominated by palm trees: Euterpe oleracea Mart. and Attalea phalerata Mart. ex Spreng in the flooded area, and Astrocaryum gynacanthum Mart. and A. aculeatum G. Mey in the well-drained soil area (terra firme). A floodplain along the borders of the stream varies from a few meters wide to almost a hundred meters according to topography and season (SALM et al. 2015). Adult crabs dig holes in the mud or hide between the aerial roots of the palm trees. Occasionally adult male and female crabs were found together in the same hole. Juvenile crabs were found on palm leaves and trunks or beneath leaf litter. A few specimens were collected outside the flooded margins of the stream, in the terra firme area.

Female crabs carried young crabs under their abdominal brood pouch. Morning field investigations revealed that $68.5 \%$ of the 108 observed crabs were males. The species is probably aggressive and territorial, since one of the chelipeds was lacking in $20 \%$ of the males and $13 \%$ of the females. The loss of chelipeds may also be attributed to autotomy as a response to predators, since skeletal remains and pereiopods of Kingsleya were frequently found in the studied area.

Etymology. The specific epithet refers to castra, the Latin word for military camp, in reference to the Brazilian Army battalion camp where this species was found.

Remarks. The new species is attributed to Kingsleya since its G1 shows the diagnostic characters of the genus, namely the marginal process distally enlarged, not overreaching the apical field of spines, the bi-lobed apical plate, the mesial process clearly separated from the apical plate and standing out from the cephalic surface of the stem; the apical plate with two partially superimposed lobes; and the field of apical spines distally divided by a terminal notch (MAGAlHães \& TÜRKAY 2008).

Kingsleya castrensis sp. nov. can be easily distinguished from K. junki Magalhães, 2003 and K. ytupora Magalhães, 1986, the other two species of the genus that occur in the Xingu River (MAGALHÃEs 2003b) by characters of the G1s apical plate. In both K. junki and K. ytupora (see MAGALHÃEs 2003b: 384, figs. 1B-D, and 385 , fig. $2 \mathrm{~B}$, respectively) the apical plate is narrow and produced distally in relation to the mesial process, whereas the apical plate of $K$. castrensis sp. nov. is distinctly enlarged and short in relation to the mesial process (Figs. 1, 3, 5 and 6). Moreover, in $K$. castrensis sp. nov. the mesial margin of the apical plates distal lobe is smooth (Fig. 1), whereas in $K$. junki the distal plate is clearly indented (Figs. 5 and 6). The distal margin of the apical plate, in mesial view, is rounded and rather narrow in K. ytupora (see MagalHães 2003: 385, fig. 2B), whereas in $K$. castrensis sp. nov. this margin is much broader rounded and enlarged (Figs. 1, 3 and 4). Another character that readily separates these two species is the presence (in K. ytupora) or absence (in $K$. castrensis sp. nov.) of a set of six to seven large, sharp teeth on the anterolateral margin of the carapace; in the latter species, this margin is fringed with a set of faint, minute teeth that lends to this margin an almost smooth appearance.

Kingsleya castrensis sp. nov. is unique among the species of the genus because of the distinctly enlarged, broadly rounded apical plate of its G1. All other species of Kingsleya have a G1 with an apical plate that is, in spite of their specific differences, much narrower, tapering and roughly subtriangular in shape (Magalhães 1986, 1990, 2003b, 2005, Magalhães \& Türkay 2008).

\section{Kingsleya junki Magalhães, 2003}

Figs. 5-6

Kingsleya junki Magalhães, 2003b: 378, fig. 1.

Material examined. 1 male (cw 26.7, cl 16.7), INPA 1708, Brazil, Pará, $2 \mathrm{~km}$ south of Jacundá $\left[4^{\circ} 27 \mathrm{~S} 49^{\circ} 07 \mathrm{~W}\right]$, right bank of Tocantins River, 7.V.1984, W. Overal leg.; 1 male (cw 30.5, cl 19.5), 1 female (cw 53.2, cl 33.7), INPA 2012, Brazil, Pará, Altamira, Leonardo da Vinci stream, $3^{\circ} 0908 " S, 52^{\circ} 0432 " W, 26 . I I I .2012$, C.S. Souza leg.; 1 male (cw: 46.1, cb: 28.7), MZUSP 32818, Brazil, Pará, Altamira, Abrigo do Chuveiro cave, IV.2009, leg. unknow. 
Distribution. The species was known only from its type locality, Vitória do Xingu, downstream from Altamira, on the left bank of Xingu River (MAGALHÃEs 2003b). The present record from Jacundá extends its distribution to the eastern Amazon region, in the middle course of the Tocantins River basin.

Ecological notes. The specimens of $K$. junki were found in the vegetated margins of the Leonardo da Vinci stream, a small, clear-water tributary on the left bank of the Xingu River. All of the crabs were collected inside holes or beneath rocks. Two couples were found, and males and females apparently shared the same hole.

Remarks. The G1 of the specimens reported herein (Figs. 5 and 6) is similar to that of the holotype of $K$. junki (see MAGALHÃES 2003b: 384, fig. 1B), although some variability can be noticed in the morphology of the apical plate, particularly in the mesial margin of the distal lobe. In the holotype, this margin is indented both proximally and distally, whereas it is more distinctly indented only in the proximal portion of this margin in the present specimens. Since such a situation can be verified in the specimens from both the Xingu River and Tocantins River basins, this might be due to intraspecific variability and, therefore, the specimen from Tocantins River was considered to be conspecific with those from the Xingu River basin.

\section{ACKNOWLEDGMENTS}

MP thanks FAPESP (Fundação de Amparo à Pesquisa do Estado de São Paulo) for providing financial support through a doctoral fellowship (2012/01334-7). JEMF is grateful to Rodolfo Salm and to biologists Anderson Prates and Cleber Sousa for their assistance during field observations. JEMF was supported by Universidade Federal do Pará (research grants PROPESP \#04/2014 and PROPESP/FADESP \#09/2014). CM thanks the Conselho Nacional de Desenvolvimento Científico e Tecnológico for an ongoing Research Grant (Proc. 303837/
2012-6). We also thank Barbara Robertson, Michael Türkay, and two anonymous reviewers for corrections and suggestions that greatly improved the manuscript.

\section{LITERATURE CITED}

Magalhães C (1986) Revisão taxonômica dos caranguejos de água doce brasileiros da família Pseudothelphusidae (Crustacea, Decapoda). Amazoniana 9(4): 609-636.

MagalHães C (1990) A new species of the genus Kingsleya from Amazonia, with a modified key for the Brazilian Pseudothelphusidae (Crustacea: Decapoda: Brachyura). Zoologische Mededelingen 63(21): 275-281.

Magalhães C (2003a) Brachyura: Pseudothelphusidae e Trichodactylidae, p. 143-297. In: Melo GAS (Ed.). Manual de Identificação dos Crustacea Decapoda de Água Doce do Brasil. São Paulo, Edições Loyola.

MagalHÃEs C (2003b) The occurrence of freshwater crabs (Crustacea: Decapoda: Pseudothelphusidae, Trichodactylidae) in the Rio Xingu, Amazon Region, Brazil, with description of a new species of Pseudothelphusidae. Amazoniana 17(3/ 4): 377-386.

MagalHães C (2005) A new species of freshwater crab (Crustacea: Decapoda: Pseudothelphusidae) from the southeastern Amazon Basin. Nauplius 12(2): 99-107.

MagalHÃes C, TÜRKaY M (2008) A new species of Kingsleya from the Yanomami Indians area in the Upper Rio Orinoco, Venezuela. (Crustacea: Decapoda: Brachyura: Pseudothelphusidae). Senckenbergiana biologica 88(2): 1-7.

Salm R, Prates A, Simões NR, Feder L (2015) Palm community transitions along a topographic gradient from floodplain to terra firme in the eastern Amazon. Acta Amazonica 45(1): 65-74. doi: 10.1590/1809-4392201401533

Smalley A (1964) A terminology for the gonopods of the American river crabs. Systematic Zoology 13: 28-31.

Submitted: 17 September 2014

Accepted: 6 December 2014

Received in revised form: 7 November 2014

Editorial responsibility: Marcos D.S. Tavares 